\section{An examination of ethnic-based consumer ethnocentrism and consumer animosity}

Consumer ethnocentrism and consumer animosity

\author{
Samshul-Amry Abdul-Latif
}

Department of Tourism, Kulliyyah of Languages and Management, International Islamic University Malaysia, Pagoh, Malaysia, and

Asmat-Nizam Abdul-Talib

Othman Yeop Abdullah Graduate School of Business, Universiti Utara Malaysia, Sintok, Malaysia
Received 6 August 2019 Revised 24 February 2020 15 June 2020 30 October 2020 Accepted 1 November 2020

\begin{abstract}
Purpose - The purpose of this study is to investigate the effects of consumer ethnocentrism and consumer animosity at the ethnic level. This study examines both effects on an ethnic majority's consumption of an ethnic minority's products and services, focusing on the relationship between two ethnic groups in Malaysia.
\end{abstract}

Design/methodology/approach - The relationship between the constructs were analyzed using the covariance-based structural equation modeling techniques with analysis of a moment structures version 21. Self-administered questionnaires were obtained from 325 Malay respondents in 2 Malaysian cities.

Findings - The results suggest that ethnic-based consumer ethnocentrism can negatively affect product judgment and product judgment can affect consumers' willingness to buy. Two significant findings were rejected as the directions of the results were not as hypothesized.

Research limitations/implications - Future research could study other ethnic groups of different countries using specific ethnic related products and/or brands.

Originality/value - This research suggests that ethnic-based ethnocentrism and ethnic-based animosity are important factors for businesses to consider as both can affect ethnic consumers' purchasing behavior. Depending on ethnic consumers' perception toward a brand, a manager may face either an opportunity or a challenge.

Keywords Consumer ethnocentrism, Consumer behavior, Product judgment, Consumer animosity, Racism, Ethnic-based consumer

Paper type Research paper

\section{Introduction}

Consumer ethnocentrism and consumer animosity, which aid marketers in understanding consumers' preference for domestic over foreign brands and products, are well-researched areas, especially in marketing and business domains (Darling and Puets, 2002; FernándezFerrín et al., 2015; Gaur et al., 2015; Riefler and Diamantopoulos, 2007; Shankarmahesh, 2006; Antonetti et al., 2019; Leonidou et al., 2019).

The substantial number of studies focusing on both critical constructs can be partially attributable to the large and increasing number of international firms operating in and

This study is funded by the International Islamic University Malaysia Research Initiative Grant Scheme Research IIUM RIGS17-009-0584. The authors would like to thank the University for generously funding the research.
Journal of Islamic Marketing (c) Emerald Publishing Limited 1759-0833 DOI 10.1108/JIMA-08-2019-0165 
establishing new markets globally (Muhamad et al., 2019; Hamzah and Mustafa, 2019; O'Hagan-Luff and Berrill, 2016). With the increasing presence of foreign brands and products in domestic markets, domestic consumers are inundated with choices. Business decisionmaking becomes even more complicated and challenging for international firms and local businesses alike when consumers are further exposed to domestic brands and products with embedded ethnic identities (Antonio and Astika, 2019; Erba et al., 2019; Grier et al., 2006).

Previous consumer ethnocentrism and consumer animosity studies have examined these constructs in various contexts and scenarios. This includes the contexts of Western and nonWestern countries, as well as developed, transitioning and emerging economies (Saffu et al., 2010; Seidenfuss et al., 2013). Consumer ethnocentrism has typically been examined between countries. There are studies that have researched the effects within economic regions (Seidenfuss et al., 2013) and between geographic regions (Ferrín and Vilela, 2015; Siemieniako et al., 2011). On the other hand, atypical but equally significant contexts such as inter-ethnic groups within domestic markets (Pentz et al., 2017; Rose et al., 2009) have rarely been examined and seem neglected.

Similarly, previous consumer animosity studies mainly focused on its effect on international foreign brands and product purchases in various contexts. The effect of consumer animosity on domestic- or ethnic-based brands and product purchases was rarely examined. Despite the presence of consumer ethnocentrism and consumer animosity between ethnic groups within a country (Abdul-Latif and Abdul-Talib, 2017; Ouellet, 2007; Shoham et al., 2006), researchers have yet to examine both constructs concurrently in one single model from the perspective of domestic ethnic groups and religion. Ouellet (2007) only included some parts of ethnic ethnocentrism and inter-ethnic animosity in his primary investigation on consumer racism and this study responds to his call to investigate these two constructs further. Moreover, researchers called for more thorough studies on consumer buying behavior in another cultural context (Hegner et al., 2017) and in developing countries (Pentz et al., 2017) to address the gap in marketing literature.

In Malaysia, the Malays (of which are mostly Muslims) are generally viewed as less affluent compared to their Chinese counterparts. In addition, the Chinese are considered as economically dominant and have a stronger business presence (Abdul-Latif and AbdulTalib, 2017; Wan Husin, 2013; Wan Husin and Ong, 2012), despite three decades of affirmative action favoring the Malays toward equalizing wealth distribution among ethnic groups (Azhar and Aliman, 2018). In general, being economically dominant could possibly lead to the Malays' feeling of animosity toward the Chinese.

Further, in lifting the Malays out of poverty (and increasing their economic status), the Malaysian Government encourages business participation and provides business-related assistance and incentives to entrepreneurial Malays (Abdul Jamak et al., 2012; Wan Husin, 2013). As a result of these affirmative actions, several Malay products and services have succeeded in entering the market with a certain degree of success. Most of these products and services carry the Malay ethnic identity and are positioned in a way to encourage Malay consumers to purchase products from their ethnic group. This could promote and lead to ethnocentric behavior among Malay consumers.

Additionally, Malay businesses are typically stereotyped as failures (Sabiu et al., 2018) and perhaps due to this, most Malay businesses positioned themselves to acquire consumer support from their ethnic group. This could also lead to ethnocentric behavior among Malay consumers. Hence, this study aims to investigate this research gap by examining the effects of consumer ethnocentrism and consumer animosity from the perspective of ethnic groups. Specifically, this study examines both effects on an ethnic majority's consumption of an 
ethnic minority's products and services. Our study focuses on the relationship between the Malays, which are the ethnic majority and the Chinese, an ethnic minority in Malaysia.

Next, we present the pertinent literature and then move to discuss the theoretical framework, define critical constructs and develop the hypotheses. We subsequently describe the methodology used and present our findings. We conclude by discussing the theoretical and managerial implications of the study, as well as its limitations and directions for future research.

\section{Literature review}

\subsection{Background of ethnic relations between the Malays and the Chinese}

Malaysia is a multi-ethnic and multi-religious country situated in Southeast Asia. In Peninsular Malaysia, there are three main ethnic groups: Malays, Chinese and Indians. The Malays are often regarded as Muslims (Idris, 2008) and also as the indigenous and predominant group (Muzaffar, 2010). Based on the Department of Statistics, Malaysia (2018), the Bumiputera or Malay constitute $69.1 \%$, the Chinese $23.0 \%$, the Indians $6.9 \%$ and others $1.0 \%$ of the population.

Generally, the migration of the Chinese to Southeast Asia, including the Peninsula region, started many centuries ago and was motivated by political, economic and religious factors (Lee, 2014). However, after the eighteenth century, British colonial forces brought significantly more Chinese (and Indian) immigrants to the Peninsula region; they helped support the capitalist industries of mining and agriculture by working as laborers and traders (Alatas, 1977).

The British implemented divide and conquer policies in which ethnic groups were separated. The majority of the Malays remained in rural areas as fishermen and farmers and participation in any other form of economic activity was discouraged (Alatas, 1977; Idris, 2008; Wan Husin, 2012). In contrast, most Chinese were placed in urban areas and their participation in business and commerce activities was encouraged (Alatas, 1977; Idris, 2008; Wan Husin, 2012). This left the Malays economically disadvantaged.

These policies continued over many decades, giving many Chinese businesspeople a head start over Malays and other ethnic groups. Over time, despite being a minority group, the Chinese became the largest ethnic community involved in both small businesses and large-scale industries (Ali, 2008; Wan Husin, 2013).

Due to Chinese economic dominance, some Malays perceived the Chinese to have vast economic resources and powerful economic influence (Wan Husin, 2012), not only in Malaysia but throughout Southeast Asia (Suryanidata, 2007). This has created a sense of resentment, distrust and suspicion among the Malays toward the Chinese (Ali, 2008; Putra, 2012). Because of this, some Malays have considered the Chinese a threat and dislike them (Ali, 2008; Gao et al., 2013; Wan Husin, 2012).

Several communal conflicts between the Malays and Chinese arose after the Second World War (Ali, 2008; Putra, 2012), but the one often referred to as the climax of inter-ethnic conflict in the modern history of Malaysia occurred on May 13, 1969 (Kua, 2011; Putra, 2012). On this date, a race riot between the Malays and Chinese exploded in Kuala Lumpur. It later spread to other major cities in Malaysia, resulting in many casualties on both sides. The period following the May 13 tragedy is considered the darkest to date for many Malaysians (Baharuddin, 2012; Putra, 2012). Although five decades have passed, the tragedy can still evoke a strong sense of anger and resentment (Klein et al., 1998) for both ethnic groups (Vengadesan, 2008). 


\subsection{Social identity theory}

In an attempt to provide theoretical insight into consumer ethnocentrism, consumer animosity and consumer behavior in general, this study draws on the social identity theory (SIT) (Tajfel, 1974; Tajfel and Turner, 1986) as the basis for the proposed model. SIT consists of three processes, which are social categorization, social identification and social comparison.

Social categorization proposes that individuals tend to categorize their social environment into categories to understand them. Once categorized, individuals will collectively define themselves based on specific unique characteristics or traits through the second process, which is social identification. Based on these characteristics or traits, these individuals form a group known as the "in-group" to source pride, self-esteem, self-image and belongingness. The final process; the social comparison is where the "in-group" compare themselves relative to "out-groups", leading to the "us versus them" mentality and attitude.

The core of SIT is that members of a group tend to seek the perceived negative aspects of an out-group to enhance their self-image. In this process, the differences between groups, as well as the similarities within groups, are often exaggerated. These exaggerations, if taken to extreme levels, may lead to conflicts between groups.

This theory can explain the behavior of group members toward another group(s); as such, in our study, the ethnic Malay is the in-group, whereas the Chinese are the out-group. Similar studies previously on consumer ethnocentrism and consumer animosity also used SIT as their theoretical basis (Ganideh and Elahee, 2016; Sierra and McQuitty, 2007; Verlegh, 2007; Zeugner-Roth et al., 2015) to explain the conceptual roots of consumer ethnocentrism and consumer animosity as the alternate antecedents to consumer behavior.

\subsection{Consumer ethnocentrism}

The general concept of ethnocentrism was introduced by Sumner (1906 cited from Shimp and Sharma, 1987) and explained the habitual inclination of people "to view their group as the center of the universe while interpreting others from their perspective" (Shimp and Sharma, 1987, p. 280). Ethnocentric persons tend to reject those who are culturally-different but accept those who are culturally-alike (Shimp and Sharma, 1987). Consumer ethnocentrism is "consumer tendencies to distinguish between products of the in-group (home country) and out-groups (foreign countries) and to avoid buying foreign products due to nationalistic reasons" (Poon et al., 2010, p. 35). Applying this concept in an economic context has resulted in the concept of consumer ethnocentrism, which became one of the most critical areas of research in consumer behavior (Chowdhury et al., 2019; Ferrín and Vilela, 2015).

Consumer ethnocentrism describes consumers' tendencies and beliefs regarding morality and appropriateness when making foreign-made product purchases (Ang et al., 2004; Fernández-Ferrín et al., 2015; Klein et al., 1998; Shimp and Sharma, 1987). In other words, ethnocentric consumers have a higher tendency to refrain from purchasing imported products, believing it better to purchase domestic products, even though these may be inferior; they tend to overestimate the quality of domestic products and underestimate foreign products (Awaluddin and Hamid, 2019; Hamin and Elliott, 2006; Muhammad and Che Razak, 2004; Sharma et al., 1995; Shimp and Sharma, 1987; Watson and Wright, 2000).

Interestingly, consumer ethnocentrism is found in countries where the majority of consumers prefer foreign products (Balabanis et al., 2001; Watson and Wright, 2000; Wang et al., 2019). Consumer ethnocentrism has been demonstrated to be, to a degree, uncertain yet dynamic and situational (Stoltman et al., 1991), which suggests ethnocentric consumers are 
sometimes only marginally ethnocentric (Chryssochoidis et al., 2007; Luque-Martinez et al., 2000; Teo et al., 2011) and do not necessarily reject foreign products. Previous studies suggest that consumers from transitional or developing countries tend to rate foreign products positively (Ettenson, 1993; Bahaee and Pisani, 2009a, 2009b, 2009c; Ahmed et al., 2018).

Many studies have found that consumer ethnocentrism is negatively related to both foreign product quality and willingness to buy foreign products (Ettenson and Klein, 2005; Klein et al., 2006, 1998; Pentz et al., 2017; Shimp and Sharma, 1987). Despite contrary results over how ethnocentric consumers may behave in their consumption, there is evidence to show that some ethnocentric consumers do not denigrate, and may even prefer, foreign products over domestic products, depending on product categories (Klein et al., 2006; Muhammad and Che Razak, 2004; Sharma et al., 1995). Consumers may even evaluate a foreign product favorably when there are no domestic products available for their consumption (Nijssen and Douglas, 2004).

\subsection{Consumer animosity}

It has been demonstrated that consumer purchases can be affected by animosity held by consumers of one country toward another country; this is known as consumer animosity (Klein et al., 1998). Consumer animosity and consumer ethnocentrism are distinct from each other, with unique antecedents and consequences, but both involve consumers' avoidance of foreign products (Fernández-Ferrín et al., 2015; Klein and Ettenson, 1999; Lee and Mazodier, 2015).

Consumer animosity is defined as "the remnants of antipathy related to previous or ongoing military, political or economic conflicts" (Klein et al., 1998, p. 91) or events that occur when countries interact with each other. Though globalization has many economic and social benefits (Lee and Mazodier, 2015), the interactions between countries may create tension, provocation, hostility, anger, displeasure and enmity (Shimp et al., 2004) among citizens or consumers. These feelings may occur unintentionally (Abd-Razak and AbdulTalib, 2012). Consumers' hatred or anger directed at a specific country is usually a response to egregious, adverse or unpleasant actions of the particular country's government, organizations, citizens and/or individuals with whom the country is perceived to be associated (Maher et al., 2010). This explains why consumers may reject foreign products from a particular country but are willing to purchase foreign products from other countries (Klein, 2002; Khan et al., 2019; Dursun et al., 2019).

Animosity can be stable or situational (Ang et al., 2004; Jung et al., 2002). Motivated by previous historical experience, stable animosity is generally a deeply embedded, negative emotion passed down from one generation to another (Abdul-Latif and Abdul-Talib, 2015b, 2017; Shoham et al., 2006) that is difficult to neutralize. Situational animosity is a negative sentiment linked to specific circumstances, making it less permanent and only occasional (Riefler and Diamantopoulos, 2007).

Consumer animosity may take years to subside (Klein et al., 1998). Previous studies have indicated that wartime atrocities may cause consumer animosity to remain strong even after many decades (Klein et al., 1998; Nijssen and Douglas, 2004). On the other hand, there is also evidence that suggests that consumer animosity can decrease over a short period (Ettenson and Klein, 2005).

Consumer animosity can transpire between developed countries - or between an underdeveloped and a developed country. In a bi-national context, studies of consumer animosity between developed countries include between the USA and France (Amine, 2008), the USA and Japan (Klein, 2002), the USA and South Korea (Maher et al., 2010), Germany 
and The Netherlands (Nijssen and Douglas, 2004) and Australia and France (Ettenson and Klein, 2005), while studies of the phenomenon between developed and underdeveloped countries include the USA and China (Witkowski, 2000) and the USA and Iran (Bahaee and Pisani, 2009a), etc.

\subsection{Product judgment}

In general, product judgment can be described as a consumer's attitude toward products, including evaluation of product quality based on country of origin (Abdul-Talib and Mohd Muttaqin, 2017; Klein et al., 1998) and ethnic origin (Abdul-Latif and Abdul-Talib, 2017). Numerous previous studies have suggested that product judgment and evaluation can have a significant influence on consumers' product purchase decisions (Carter and Maher, 2014; Hinck, 2005; Nijssen and Douglas, 2004; Rose et al., 2009).

While most previous studies found a positive relationship between product judgment and willingness to buy (Abdul-Latif and Abdul-Talib, 2017; Ahmed et al., 2013; Klein et al., 1998; Wang and Chen, 2004), there were also studies that found no relationship (Maher and Mady, 2010) and a negative relationship (Abdul-Latif and Abdul-Talib, 2015a).

\subsection{Ethnic-based consumer ethnocentrism, product judgment and willingness to buy}

Ethnocentric consumers believe that, by purchasing domestic products, they are patriotic, nationalistic and morally right (Klein et al., 1998) and that purchasing imported products could harm the domestic economy which could result in local job loss or unemployment (Klein and Ettenson, 1999; Shimp and Sharma, 1987). Ethnocentric consumers feel that it is not patriotic or nationalistic to economically support foreign countries through purchases, as national interests and economic well-being are threatened by imports; they feel that domestic producers deserve "help" and that this justifies purchases of domestically produced products (Shimp and Sharma, 1987). This demonstrates that consumers' preference for choosing "home" over foreign products implies the "in-group and out-group" formation of SIT (Tajfel and Turner, 1986) and "us versus them" (Klein, 2002; Shimp and Sharma, 1987), even at the ethnic or sub-national level (Ouellet, 2007). Although it is quite common to evaluate consumer ethnocentrism at the international level (Ferrín and Vilela, 2015), it is logical to evaluate and operationalize consumer ethnocentrism at different levels, namely, national ethnocentrism, regional ethnocentrism (Fernández-Ferrín and BandeVilela, 2013; Ferrín and Vilela, 2015; Siemieniako et al., 2011) and ethnic ethnocentrism (Ouellet, 2007).

Consumer ethnocentrism is prominent in developed countries rather than developing countries (Wang and Chen, 2004; Yagci, 2001), which suggests that consumers in developed countries may generally regard products from developing countries to be inferior, compared to domestic locally produced brands and products (Balabanis et al., 2001; Karoui and Khemakhem, 2019; Kipnis et al., 2019).

In a similar vein, consumers who identify themselves as being from a certain locality can be ethnocentric and prefer certain brands and products with a regional flavor (Ferrín and Vilela, 2015). From a sub-national perspective, this is further extended to suggest that a certain ethnic group can be more ethnocentric than its fellow citizens from other ethnicities (Vida et al., 2008) and may view any products offered by an ethnic group other than its own as sub-standard and inferior (Ouellet, 2007). However, consumers sometimes have limited product choices available to them (Nijssen and Douglas, 2004; Watson and Wright, 2000). Therefore, despite ethnocentricity and a preference for products from their own ethnic group, ethnic consumers are more or less "forced" to buy products from outside their group.

Based on the review above, the following hypotheses are made: 
H1a. Ethnic-based consumer ethnocentrism (EBCE) negatively affects the ethnic majority consumers' willingness to buy products from the ethnic minority group; and

H1b. EBCE negatively affects the ethnic majority consumers' judgment of products from the ethnic minority group.

\subsection{Ethnic-based consumer animosity, product judgment and willingness to buy}

Consumer animosity is not only useful in explaining international phenomena but also applicable in investigating domestic situations (Hinck, 2005; Shimp et al., 2004). Previous studies have investigated animosity at a regional level (Hinck, 2005; Huang et al., 2015; Shimp et al., 2004) and at an ethnic level (Abdul-Latif and Abdul-Talib, 2017; Ouellet, 2007; Shoham et al., 2006).

There are several factors underlying consumer animosity. According to Hinck (2005), "domestic animosity" is the reason that East German consumers harbored economic animosity toward West German products, with measured levels that were "stronger than the effects of animosity in previous cross-national studies by Klein et al. (1998) and Witkowski (2000)" (Hinck, 2005, p. 97). Recently, Huang et al. (2015) revealed that the animosity between the North and South Taiwanese was caused by social and economic factors, not only factors related to war (Klein et al., 1998).

Other examples of domestic animosity include in:

Spain (where many Basques are quite critical toward the rest of the country), or in Great Britain (where the English, Scots, and Welsh may very possibly feel some domestic animosity beyond football rivalry) (Hinck, 2005, p. 98).

In a similar vein, Rose et al. (2009) suggested that two different ethnic groups, the Arabs and Jews of Israel, have different levels of animosity when purchasing international foreign products of Italy and the UK.

Considering animosity from the ethnic-based perspective, it could be that ethnic consumers with animosity tend to reflect their anger over a specific incident or event (Hill and Paphitis, 2011) on to another ethnic group through buying behavior, thus showing disapproval of certain actions performed by the targeted ethnic group that were earlier perceived to be egregious. Ethnic consumers with animosity tend to avoid buying products they perceive to be associated with or made by the disparaged ethnic group (Hill and Paphitis, 2011; Ouellet, 2007). Avoiding purchases could also be influenced by ethnic consumers' moral and ethical beliefs in deciding what is considered good or bad behavior (Hill and Paphitis, 2011). Further, consumers' purchase decisions can also be influenced by their negative experiences in another country or with people from another country (Riefler and Diamantopoulos, 2007). In a similar vein, consumers' negative experiences that affect their purchase decision could also be examined from the perspective of ethnicity differences instead of focusing on the country level.

However, regardless of the level of animosity, consumers may still have good opinions of brands and products from the targeted country, but these may not necessarily be enough to influence their product purchase (Ettenson and Klein, 2005; Klein et al., 1998). Several studies have found that the dimensions of consumer animosity such as war, economic, political, religious and personal reasons (Klein, 2002; Riefler and Diamantopoulos, 2007) were independent of product judgments (Hong and Kang, 2006; Klein et al., 1998).

\section{Consumer ethnocentrism and consumer animosity}


On the other hand, there was also evidence suggesting that product judgment can be affected by consumer animosity (the second study in Ettenson and Klein, 2005; Mostafa, 2010; Shoham et al., 2006). Product judgments on domestically produced goods can be negatively affected by animosity across ethnicities in a country, especially concerning products with strong embedded ethnic identities (Shoham et al., 2006; Leonidou et al., 2019; Antonetti et al., 2019; Gupta and Singh, 2019). Nevertheless, consumer animosity "may have little impact on product judgments unless these [egregious events or] activities are thought about at the time the judgments are made" (Hong and Kang, 2006, p. 238). When there is a recent event that could lead to animosity toward an ethnic group, this animosity may lead to product denigration; whereas, when it is less recent, consumers may hold animosity but not necessarily denigrate the target product (Shoham et al., 2006).

Based on the review above, it is hypothesized that:

$H 2 a$. Ethnic-based consumer animosity (EBCA) negatively affects the ethnic majority consumers' willingness to buy products from the ethnic minority group; and

$H 2 b$. EBCA negatively affects the ethnic majority consumers' judgment on products from the ethnic minority group.

Previous studies have suggested that consumers' attitudes toward any brands and products considered as foreign can be affected when there are contextual issues associated with the said product (Abdul-Talib and Mohd Muttaqin, 2017). When such a situation is applied within the ethnic context and perspective, a consumer is also expected to evaluate available alternate products.

Based on the above, it is proposed that the ethnic majority Malays' product judgment and willingness to buy ethnic minority Chinese products have a positive relationship as below:

H3. Ethnic majority of consumers' product judgment positively affects the willingness to buy ethnic minority's products.

\section{Methodology}

\subsection{Respondents}

The data was obtained through a convenience sampling method and the drop and collect technique was adopted via a pre-tested self-administered questionnaire (Brown, 1987). This approach was used in this study as it has been successfully used in many consumer-based research, including Ahmed and d'Astous (2007), Balabanis and Diamantopoulos (2011) and Khan et al. (2017). Also, the approach was used mainly to efficiently identify potential samples and obtain a higher level of participation and responses within a shorter period of time.

The respondents targeted were Malays residing in two major cities in Malaysia; the Malay population in these cities is significant, forming more than 35\% of the total (Liu, 2006; Olmedo et al., 2015). The questionnaires were distributed to organizations where the Malays are predominant. These organizations include a higher learning institution, a state government office and a private limited company. This is so that the sampling distribution between students and used persons is more or less well-distributed. Furthermore, students are significant consumers and understanding their consumption patterns is vital for future planning. With the assistance of their respective human resource or administration representatives, the questionnaires were then distributed to Malay respondents only. 
Malays are generally Muslims (Alatas, 1977; Idris, 2008; Zakaria et al., 2020) and can be identified through their physical appearance, including skin color, clothing and name.

While there are various recommended numbers of the respondent (Anderson and Gerbing, 1988; Hair et al., 2009), this study adopted the recommendation made by Kline (2011), where at least 200 respondents are required. From a total of 350 questionnaires given out, 325 were returned with responses. A total of 25 questionnaires were removed due to incompleteness and straight-lining responses, leaving 300 questionnaires for further analysis. The offline approach was chosen as a mechanism to ensure a higher response rate as the representatives ensured that all questionnaires distributed were subsequently collected.

\subsection{Survey design}

The questionnaires were divided into three sections, namely, a full-page depicting 29 various Malaysian Chinese products and services with brand names, construct measurement scales that had been adapted from previous studies and, finally, background information for the respondents to complete.

Based on previous studies (Abdul-Latif and Abdul-Talib, 2015a; Li et al., 2013), the main categories of the brand names used were in the services and food and beverage (F\&B) industries. Within the F\&B industry, brands for household items such as flour, cooking oil and packaged drinks were used; whereas within the services industry brands included bookstores, supermarket stores and franchised restaurants, etc. The brand names used included common and familiar household brands in Malaysia, such as Yeo's, Massimo and Hup Seng [1]. Following previous studies (Khan et al., 2017; Qing et al., 2012), we expected our respondents to be able to provide reliable and valid responses as the product categories and brands used were commonly known, affordable and easily available (AbdulLatif and Abdul-Talib, 2015a; Abdul-Talib and Abdul-Latif, 2015). Additionally, the product categories and brands used in the questionnaire, carry a relatively non-Malay identity.

In the background section, respondents were required to state their gender, age group, employment category and education level. Respondents were then required to rank the modified scales to determine "willingness to buy" (Ettenson and Klein, 2005) using 5 items, product judgment (Ettenson and Klein, 2005) using 6 items, "EBCE" (Shimp and Sharma, 1987) using 10 items and "EBCA" (Klein et al., 1998) using 9 items. These measurement scales were measured through a five-point Likert-type scale ranging from "Strongly Disagree," "Disagree," "Neutral," "Agree" to "Strongly Agree." The measurement scales were standardized mainly to avoid respondents' potential confusion and to facilitate ease of answering the questionnaire. The measurement items contained both positive and negatively-worded items. The negative-worded items were retained in the questionnaire to avoid potential bias (Devellis, 2003). The scores for negatively worded items in the measurement scales were later reverse-coded and adjusted accordingly (Netemeyer et al., 2003).

\subsection{Common method bias}

In behavioral research, it is known that common method biases can be a potential problem. Common method bias occurred when the variance observed among measures is "attributable to the measurement method rather than to the constructs the measures represent" (Podsakoff et al., 2003, p. 879). Data collected from respondents through a crosssectional approach can lead to common method biases, which may suggest inaccurate correlations. As such, this study took four remedial steps as recommended by Podsakoff et al. (2003) to control common method biases. First, when distributing the questionnaires, 
the respondents were assured and guaranteed anonymity in protecting the confidentiality of their responses. Then, the respondents were asked to be as honest as possible when answering and that there are no specific desired answers to the questions.

Additionally, this was also indicated in the questionnaire's introduction page. Subsequently, construct items that were found to be ambiguous were clarified or removed during a pre-test survey. Finally, the study conducted Harman's single factor test to examine the unrotated factor solution so that the total factors accounting for the variance in the variable could be specified. Common method bias exists when one single factor emerges that explains the majority or 50\% of the variance (Lowry and Gaskin, 2014; Podsakoff et al., 2003). The results from the test run on statistical package for the social sciences (SPSS) Statistics version 21 indicated that the most covariance explained by a factor is $39.1 \%$. Due to the increasing dispute regarding Harman's test, the study undertook further steps to address common method bias. In the measurement model, the common method bias adjusted composite approach was applied by creating a common method factor that resulted in lower item weights (Gaskin, 2016).

\subsection{Data analysis and approach}

3.4.1 Analytical methods. The demographic data were analyzed using SPSS Statistics version 21. The causal relationships between the constructs were analyzed using the co-variance-based structural equation modeling approach, using analysis of a moment structures version 21 . Before applying the structural modeling procedure, the measurement model was estimated as recommended (Anderson and Gerbing, 1988). Confirmatory factor analysis (CFA) with maximum likelihood estimation was performed to assess the measurement model and to evaluate data quality, reliability and validity of the constructs, followed by structural modeling to assess the overall fit of the proposed model and test the hypotheses.

\section{Results}

\subsection{Demographic profile}

Of the usable 300 questionnaires, $53 \%$ of the respondents were women and $47 \%$ were men. The highest percentage of respondents $(31 \%)$ was from the $26-35$ years of age segment, followed by three other segments: $18-21,22-25$ and $36-45$ (18\% for each group). A large portion of the respondents of $42 \%$ were used, while $36 \%$ were students at institutions of higher learning, $7 \%$ were unemployed and $15 \%$ were retired. The education levels of the respondents were high, with $74 \%$ having tertiary education, of which $33 \%$ held a bachelor's degree, $30 \%$ held a diploma, $10 \%$ a master's degree and $2 \%$ a $\mathrm{PhD}$ degree. Of the remainder, $26 \%$ of the respondents had completed secondary education and about $1 \%$ had a primary education level only. Refer to Table 1 below.

\subsection{Measurement model}

Unidimensional is achieved when construct items have acceptable factor loadings for the respective latent construct of above 0.6 (Awang et al., 2015). One item of product judgment (PJ5) and one item of ethnic-based consumer animosity (CA2) were removed due to low factor loadings. All of the other construct items scored between 0.67 and 0.87 .

Convergent validity was achieved as all of the construct items were statistically significant and each construct's average variance extracted (AVE) values were above 0.5. Discriminant validity was achieved, as the correlations between the constructs were less than 0.85 . Additionally, maximum shared variance (MSV) was presented to signify the discriminant validity. Using modification indices, three redundant items from EBCE - item CET 3 and EBCA - items CA1 and CA3 were removed. Furthermore, the square correlations 


\begin{tabular}{|c|c|c|c|c|c|c|c|c|}
\hline \multicolumn{9}{|c|}{ Age group } \\
\hline $\begin{array}{l}\text { Male } \\
\text { Female }\end{array}$ & $\begin{array}{c}18-21 \\
16(5 \%) \\
38(13 \%)\end{array}$ & $\begin{array}{c}22-25 \\
20(7 \%) \\
33(11 \%)\end{array}$ & $\begin{array}{c}26-35 \\
39(13 \%) \\
53(18 \%)\end{array}$ & $\begin{array}{c}36-45 \\
33(11 \%) \\
20(7 \%)\end{array}$ & $\begin{array}{r}46-55 \\
26(9 \%) \\
8(3 \%)\end{array}$ & $\begin{array}{l}56-65 \\
4(1 \%) \\
3(1 \%)\end{array}$ & $\begin{array}{c}66 \text { above } \\
3(1 \%) \\
4(1 \%)\end{array}$ & $\begin{array}{c}\text { Total } \\
141(47 \%) \\
159(53 \%)\end{array}$ \\
\hline Total & $54(18 \%)$ & $53(18 \%)$ & $92(31 \%)$ & $53(18 \%)$ & $34(11 \%)$ & $7(2 \%)$ & $7(2 \%)$ & $300(100 \%)$ \\
\hline $\begin{array}{l}\text { Male } \\
\text { Female } \\
\text { Total }\end{array}$ & $\begin{array}{l}\text { category } \\
\text { Student } \\
31(10 \%) \\
78(26 \%) \\
109(36 \%)\end{array}$ & $\begin{array}{c}\text { Exec } \\
28(9 \%) \\
22(7 \%) \\
50(17 \%)\end{array}$ & $\begin{array}{l}\text { Manager } \\
13(4 \%) \\
12(4 \%) \\
25(8 \%)\end{array}$ & $\begin{array}{l}\text { Entrep } \\
24(8 \%) \\
12(4 \%) \\
36(12 \%)\end{array}$ & $\begin{array}{r}\text { Unemp } \\
6(2 \%) \\
14(5 \%) \\
20(7 \%)\end{array}$ & $\begin{array}{c}\text { Prof } \\
6(2 \%) \\
10(3 \%) \\
16(5 \%)\end{array}$ & $\begin{array}{l}\text { Retired } \\
33(11 \%) \\
11(4 \%) \\
44(15 \%)\end{array}$ & $\begin{array}{c}\text { Total } \\
141(47 \%) \\
159(53 \%) \\
300(100 \%)\end{array}$ \\
\hline $\begin{array}{l}\text { Educatic } \\
\text { Male } \\
\text { Female } \\
\text { Total }\end{array}$ & $\begin{array}{l}\text { tegory } \\
\text { P.S. } \\
1(<1 \%) \\
1(<1 \%) \\
2(1 \%)\end{array}$ & $\begin{array}{c}\text { H.S. } \\
41(14 \%) \\
33(11 \%) \\
74(25 \%)\end{array}$ & $\begin{array}{l}\text { Diplom } \\
37\left(12^{\circ}\right. \\
54\left(18^{\circ}\right. \\
91\left(30^{\circ}\right.\end{array}$ & $\begin{array}{r}\text { B. } \\
49(1 \\
49(1 \\
98(3\end{array}$ & $\begin{array}{l}6 \%) \\
6 \%) \\
3 \%)\end{array}$ & $\begin{array}{c}\text { M.D } \\
9(3 \%) \\
20(7 \%) \\
29(10 \%)\end{array}$ & $\begin{array}{c}\mathrm{PhD} \\
4(1 \%) \\
4(1 \%) \\
6(2 \%)\end{array}$ & $\begin{array}{c}\text { Total } \\
141(47 \% \\
159(53 \%) \\
300(100 \%)\end{array}$ \\
\hline
\end{tabular}

Notes: Exec - Executive level; Entrep - Entrepreneurs; Prof - Professionals; P.S. - Primary school qualification; H.S. - High school certificate; B.D - Bachelor's degree; M.D - Master's degree; PhD Philosophical doctorate

Consumer
ethnocentrism
and consumer
animosity

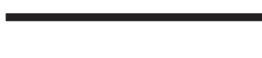

Table 1.

Demographic details of the respondents

for each construct were less than the AVE with the items measuring that construct indicating discriminant validity as per Table 2 .

Construct validity was achieved by satisfying the fit indices that reflected data and model fit. Hair et al. (2009) recommended the use of at least one fitness index from each category of model fit, namely, absolute, incremental and parsimonious. The normed $\chi^{2}$ was 2.192, achieving a parsimonious fit (Wheaton et al., 1977). The comparative fit index (CFI) and the Tucker-Lewis index (TLI) were 0.952 and 0.944, respectively (Bentler, 1990; Bentler and Bonett, 1980), which signaled incremental fit. Absolute fit is considered achieved, as the root mean square error of approximation (RMSEA) was 0.063 . The goodness of fit index (GFI) was 0.902 (Browne and Cudeck, 1993). As the indices met recommended guidelines, the overall model fit was considered reasonable and acceptable, as shown in Figure 1.

The Cronbach's $\alpha$ values of all constructs ranged from 0.812 to 0.925 , indicating internal reliability. The composite reliabilities (CR) were acceptable, ranging from 0.813 to 0.926 . The AVEs ranged from 0.521 to 0.638 , indicating that all constructs achieved convergent validity (Table 2). Moreover, McDonald construct reliability or $\operatorname{MaxR}(\mathrm{H})$ was estimated with all constructs achieving values of above 0.7. Overall, it was concluded that the constructs were all reliable and valid. The next step was to examine the structural model results, as shown in Figure 2 (Table 3 ).

\begin{tabular}{lccccc}
\hline Constructs & Cronbach's & CR & AVE & MSV & MaxR(H) \\
\hline PJ & 0.812 & 0.813 & 0.521 & 0.009 & 0.816 \\
EBCE & 0.925 & 0.926 & 0.611 & 0.587 & 0.929 \\
EBCA & 0.894 & 0.895 & 0.632 & 0.578 & 0.905 \\
WTB & 0.872 & 0.876 & 0.638 & 0.587 & 0.885
\end{tabular}

Table 2.

Cronbach's alpha; composite

Notes: CR - Composite reliabilities; MSV - Maximum shared variance; $\operatorname{MaxR}(\mathrm{H})$ - McDonald construct reliabilities; AVE and reliability 


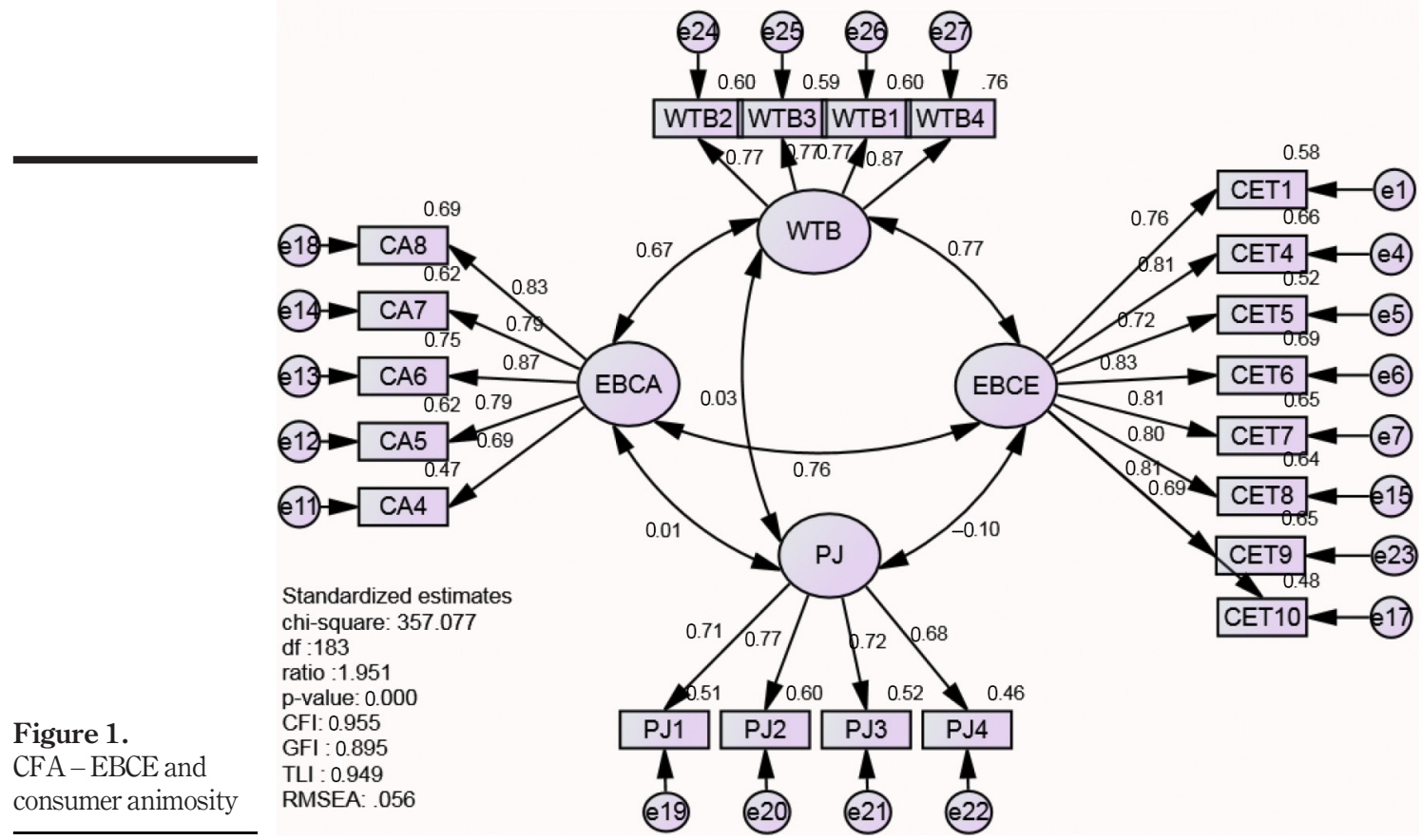

\subsection{Structural modeling}

A structural model was estimated to test the hypotheses and is presented in Table 4. The overall results of the statistics suggested that the model and data fit reasonably. The chisquare value $\left(\chi^{2}=357.077, \mathrm{df}=183, p=0.000\right.$, ratio $\left.=1.951\right)$ and goodness-of-fit indices $($ RMSEA $=0.056 ; \mathrm{CFI}=0.955 ; \mathrm{GFI}=0.895 ; \mathrm{TLI}=0.949)$ suggested that the model fits the data at a reasonable level. The structural results are shown in Figure 2.

The results indicated that the relationship between $\mathrm{EBCE}$ and willingness to buy $(\mathrm{H} 1 \mathrm{a})$ was significant $(p<0.001)$ but was positively related, suggesting that ethnocentric Malay consumers do have a willingness to buy Chinese products and services. Thus, H1a was not supported and was therefore rejected. The relationship between EBCE and product judgment $(H 1 b)$ was significant $(p<0.05)$ and negatively related, suggesting that Malay consumers' judgment of Chinese products and services can be negatively affected by EBCE. Therefore, $H 1 b$ was supported and accepted.

The relationship between EBCA and willingness to buy $(H 2 a)$ was significant $(\phi<0.05)$ but not as hypothesized. Thus, H1a was not supported and was, therefore, rejected. However, this result may suggest that Malay consumers with animosity are still willing to buy Chinese products and services.

The hypothesized relationship $(H 2 b)$ between EBCA and product judgment was not significant and was rejected, indicating that consumers' judgment of Chinese products was not affected by EBCA. The relationship between product judgment and 


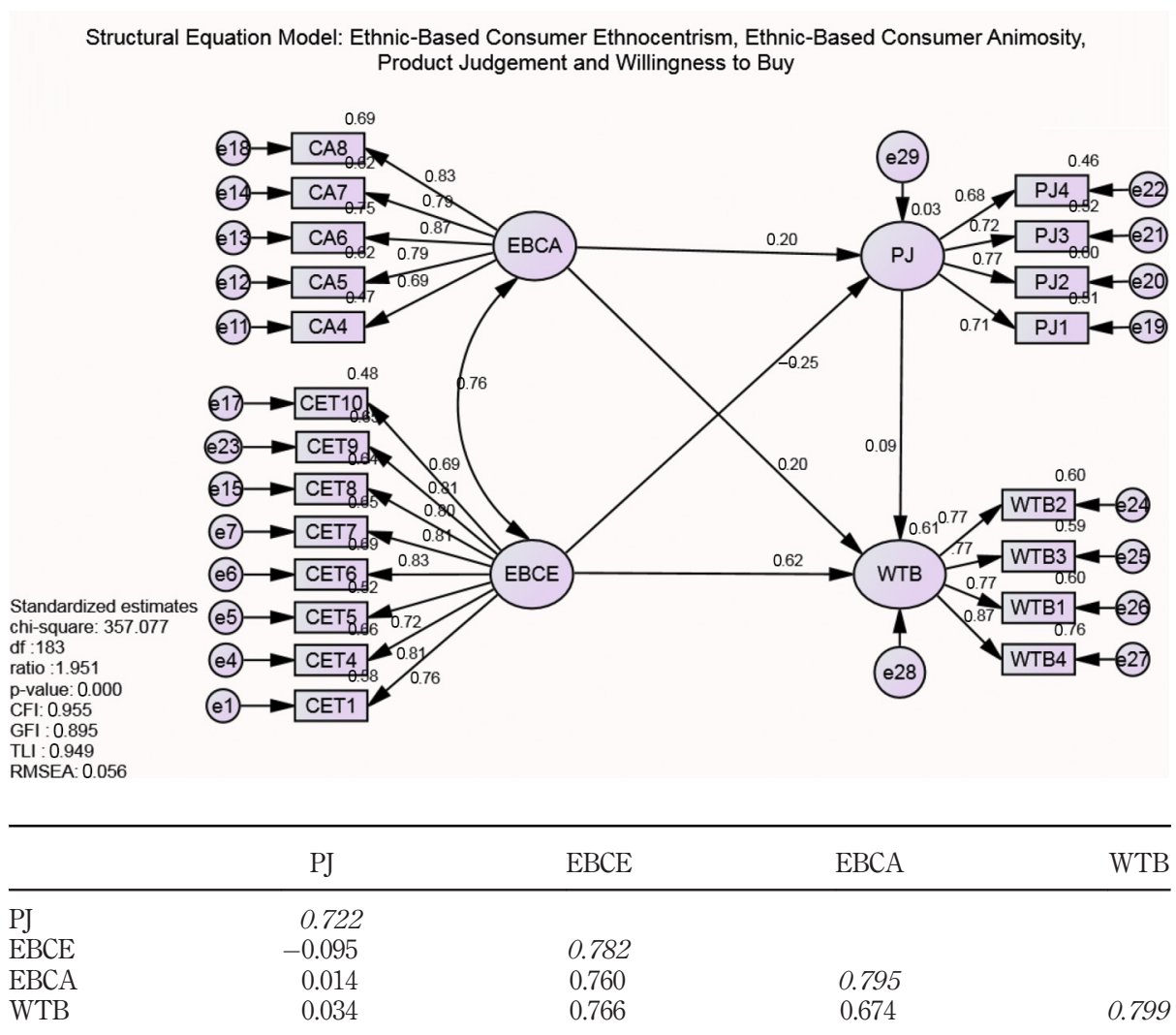

Consumer ethnocentrism and consumer animosity

Figure 2. Structural equation modelling - EBCE and consumer animosity

Notes: EBCE - ethnic-based consumer ethnocentrism; EBCA - ethnic-based consumer animosity; PJ product judgment; WTB - willingness to buy

Table 3.

AVE and squared correlations

\begin{tabular}{llccccc}
\hline Hypotheses & Paths & Estimates & Std. errors & $t$-values & $p$-values & Decision \\
\hline$H 1 a$ & $\mathrm{EBCE} \rightarrow$ WTB & 0.556 & 0.076 & 7.296 & $<0.001^{* * * *}$ & Reject \\
$H 1 b$ & $\mathrm{EBCE} \rightarrow$ PJ & -0.187 & 0.082 & -2.266 & $0.023^{* * *}$ & Accept \\
$H 2 a$ & $\mathrm{EBCA} \rightarrow$ WTB & 0.185 & 0.079 & 2.342 & 0.019 & Reject \\
$H 2 b$ & $\mathrm{EBCA} \rightarrow \mathrm{PJ}$ & 0.177 & 0.096 & 1.832 & 0.067 & Reject \\
$H 3$ & $\mathrm{PJ} \rightarrow \mathrm{WTB}$ & 0.114 & 0.058 & 1.953 & $0.051^{*}$ & Accept
\end{tabular}

Notes: EBCE - Ethnic-based consumer ethnocentrism; EBCA - Ethnic-based consumer animosity; PJ Product judgment; WTB - Willingness to buy; ${ }^{*} p<0.10,{ }^{* * *} p<0.05,{ }^{* * * *} p<0.001$

Table 4.

Results of the structural model

willingness to buy was found to be significant $(p<0.10)$ as hypothesized and the result suggested that consumers' product judgment can positively affect their willingness to buy Chinese products and services, thus $H 3$ was partially supported and accepted. 


\section{Discussion}

The purpose of this study was to investigate the effects of the EBCE and EBCA of an ethnic majority's consumers on their judgment and purchase of the products and services of an ethnic minority. These effects were demonstrated by ethnic Malay consumers' consumption of ethnic Chinese products and services, namely, household items such as flour, cooking oil and packaged drinks and bookstores, supermarket stores and franchised restaurants. These findings may have several practical and managerial implications for both international and domestic businesses.

The results may suggest that ethnic majority consumers are indeed ethnocentric, but somehow this does not cause this group to disregard products and services from the ethnic minority. The results may suggest that the ethnocentric Malay consumers may judge Chinese products and services as negative generally, which can affect their overall purchase behavior negatively. However, the results also suggest - perhaps under certain circumstances, i.e. without prior product evaluation or judgment - those ethnocentric Malay consumers are willing to purchase products and services from ethnic Chinese (Abdul-Latif and Abdul-Talib, 2017).

Generally, ethnic majority consumers agreed that it was best to choose products from their own group over products from other ethnic groups to support businesses from their ethnic group, even if it may cost slightly more. However, it may be difficult for ethnic majority consumers to choose only products from their ethnic group when there are limited choices available to them (Abdul-Latif and Abdul-Talib, 2017; Wan Husin, 2013). Contextually, the number of ethnic majority Malay consumers involved in businesses is limited (Bustaman and Yunus, 2012; Jamaluddin and Dickie, 2011; Minai et al., 2012; Wan Husin, 2013) and most operate businesses that are small in size. Even where there are product and service alternates available from Malay businesses or entrepreneurs, there has been a lack of market coverage (Asri and Ghani, 2012), with only certain states or regions being covered by the businesses. This has especially been the case where budding businesses have attempted to expand their markets with limited capital, exposure and experience.

Similarly, ethnic majority consumers may hold animosity against the ethnic minority group in general but did not translate that into their purchasing behavior; it did not stop them from having positive product judgment and are willing to purchasing products and services from the ethnic minority group. Based on the retained items (as per the Appendix), contextually, Malay consumers felt that they were economically marginalized and discriminated against by the Chinese and that the Chinese should "pay" for their actions. Malay consumers also felt that the Chinese tended to take advantage of the Malays, were unfair in business and unreliable as business partners, especially when dealing with Malays. These feelings and perceptions can be associated with the fact that the current overall participation of Malays in businesses and economic activities is low compared to that relating to the Chinese (Ali, 2008; Asri and Ghani, 2012; Idris, 2008; Wan Husin, 2013).

Additionally, the results suggest that the ethnic majority of consumers were ethnocentric and filled with animosity and because of that did not judge Chinese products and services from the ethnic minority group positively. Nevertheless, this did not stop the ethnic majority of consumers from intending to purchase products and services from the ethnic minority group. Contextually, this could be explained by the limited number of Malay products and services in the marketplace: Malay consumers were willing to buy Chinese products to satisfy their consumption needs. At a different level of analysis, the results of this study echo the findings of Watson and Wright (2000) and Nijssen and Douglas (2004), who noted 
that foreign alternate products were sought when domestic products were not available for consumers' consumption.

In general, marketers need to investigate the levels of both EBCA and consumer ethnocentrism within their territories of operations and markets, both internationally and domestically, to provide proper guidance for product positioning, branding and market entry decisions. Ethnic minority-owned companies can re-evaluate their marketing communications strategies and reposition or rebrand themselves to be more appealing to the ethnic majority. Alternately, marketers can consider de-emphasizing the ethnic images attached to their products and services and perhaps consider adopting a neutral or national image instead.

Additionally, proper investigation regarding potential gains and losses needs to be conducted thoroughly, as businesses looking to attract other ethnic groups run the risk of losing the support of current customers from their own ethnic group (Ouellet, 2007). This scenario is also applicable to companies owned or controlled by a majority ethnic group seeking to target minority groups. Perhaps "multi-local" or even ethno-marketing (Pires and Stanton, 2000) strategies might be a useful approach when entering a multi-ethnic market, so as not to lose current customers while trying to gain new ones (Vida et al., 2008).

Another consideration that marketers can study is that, once the levels of $\mathrm{EBCE}$ and EBCA are known, marketers can opt for joint ventures with influential companies perceived to represent a particular ethnic group (Gomez, 2003). This approach can be part of a business's international strategies for entering new markets known to be ethnocentric and have ethnic-based animosity (Fernández-Ferrín et al., 2015). The results of this study also support previous studies that used constructs from international research to explain domestic phenomena (Abdul-Latif and Abdul-Talib, 2017; Hinck, 2005; Shoham et al., 2006).

In addition to its practical and managerial implications, this article also contributes to the body of scientific marketing research especially in Islamic marketing and branding (Wilson et al., 2013; Wilson and Grant, 2013). Both measurement scales can be used in multi-ethnic countries with similar demographics to Malaysia in investigating ethnic-based ethnocentrism and ethnic-based animosity among their consumers. The countries may include but are not limited to Indonesia, India, The Philippines, Thailand and several countries in Africa.

\section{Implications}

These findings add further empirical support that both consumer ethnocentrism and consumer animosity are not only applicable and measurable between countries but instead, it can be measured at the ethnic or sub-national level (Abdul-Latif and Abdul-Talib, 2017; Ouellet, 2007; Seidenfuss et al., 2013). This is a very important idea to grasp as in this global and "almost borderless" era; there are increasing numbers of countries with multi-ethnicities and religions (Wilson et al., 2013; Wilson and Grant, 2013; Wilson and Liu, 2011). Perhaps, the definition of both consumer ethnocentrism and consumer animosity should be reexamined to include the domestic and ethnic-level perspective.

It is interesting to note that the Buy Muslims First or \#BMF movement, which was started by a certain group of Malaysian Muslims using the Facebook platform in December 2018, gained an exponential number of over 1.6 million followers in just several days in 2019 (FMT, 2019). The campaign urged the Bumiputera Muslim community to support products and services provided by Muslims, stating that the campaign was aimed at strengthening the economic power of Muslims and giving them a competitive edge. It was argued that this effort would lead to unity among ethnic groups in Malaysia as it lessens the economic gap between the ethnic groups (Khairil Anwar, 2019). This could lead to negative repercussions, 
as it can be seen and interpreted as "Buy Non-Muslims Last" or boycott (Abdul-Latif and Abdul-Talib, 2015b). Similarly, it is interesting to recap what Wilson et al. (2013) observed that there are Islamic nations in the Middle East which demonstrated the importance of ethnicity and culture over religion and nation.

In view of reaching racial harmony among ethnic groups in Malaysia, the relevant Malaysian authorities should promote "Buy Malaysian products" and perhaps highlight the possible repercussions or effects of supporting economic groups based on their ethnicity or religion, as all Malaysians are responsible in contributing to the economic growth and prosperity of their country. From a broader perspective, the relevant authorities must invest more in promoting programs and activities which could foster strong and healthy relations among Malaysians.

\section{Limitations and future research directions}

There are several limitations to this study. First, this study did not use the reconceptualized measurements for consumer ethnocentrism (Sharma, 2014; Siamagka and Balabanis, 2015) and consumer animosity (Hoffmann et al., 2011). Perhaps future research could incorporate these reconceptualized measurements and examine their applicability in a domestic and ethnic context.

Though previously consumer ethnocentrism and consumer animosity were both used together in one model (Ettenson and Klein, 2005; Klein et al., 1998; Rose et al., 2009), they were configured differently. Future research could investigate the use of the animosity model (Klein et al., 1998) in a domestic and ethnic context.

In this study, we used various collections of familiar Malaysian Chinese brands, products and services to prime our respondents. Perhaps for future studies, researchers could use specific Malaysian Chinese products and examine the possibilities of brand hate (Zarantonello et al., 2016) by other ethnic groups. Specific brands could also be examined as the nature of certain products and services may vary, which could influence consumers' consumption. Researchers could also investigate whether ethnic Malays are affected in their purchase decision-making on Malaysian Chinese products and/or brands with and without Halal certification (Alam and Sayuti, 2011).

In this study, we used a drop and collect technique and the samples that we obtained were an approximate representation of the Malay population in Malaysia in terms of gender and age. Perhaps other techniques such as the mall-intercept technique can be used in future studies.

As this study was done prior to the worldwide COVID-19 pandemic, future studies should examine whether there are changes in the effects of consumer ethnocentrism and consumer animosity on consumers' purchasing behavior. Perhaps consumer ethnocentrism and consumer animosity can be influenced by many other external factors, including political conditions. This may be a useful area to research as there is not yet a longitudinal study to investigate any changes to the previously used constructs. Finally, consumer ethnocentrism and consumer animosity should be examined through the interpretation of the Quran and Sunnah, as there are many verses in the Quran (such as Surah Ar-Rum 30:22, Al-Hujurat 49:13) which promotes (ethnic/racial) unity.

O mankind, indeed, We have created you from male and female and made you peoples and tribes that you may know one another. Indeed, the most noble of you in the sight of Allah is the most righteous of you. Indeed, Allah is Knowing and Acquainted. Quran 49:13 (AlHujurat). 


\section{Note}

1. These brands have a significant presence and shelve space in hypermarkets in Malaysia. Both Yeo's and Hup Seng are one of the oldest brands in Malaysia, which were established in 1957 and 1958, respectively. Both brands have won several brand awards. Source: www.yeos.com.my/ corporate-info/our-milestone/ and www.thebrandlaureate.com/special-edition-world-awards/ malaysia-edition/. Both accessed on February 7, 2020. While in the bread segment, Massimo is the biggest contender to market leader Gardenia (Abdul-Latif and Abdul-Talib, 2015b).

\section{References}

Abd-Razak, I.S. and Abdul-Talib, A.N. (2012), "Globality and intentionality attribution of animosity: an insight into the consumer boycotts in the Muslim dominant markets", Journal of Islamic Marketing, Vol. 3 No. 1, pp. 72-80, doi: 10.1108/17590831211206608.

Abdul Jamak, A.B.S., Salleh, R., Sivapalan, S. and Abdullah, A. (2012), "Micro business enterprise of Bumiputera Malays", Malaysia. African Journal of Business Management, Vol. 6 No. 22, pp. 6504-6510, doi: 10.5897/AJBM11.2467.

Abdul-Latif, S.A. and Abdul-Talib, A.N. (2015a), "An examination of the effects of consumer racism and consumer ethnocentrism on willingness to buy products associated with ethnic Chinese", Australia New Zealand International Business Academy Conference, ANZIBA, Melbourne, pp. 1-42.

Abdul-Latif, S.A. and Abdul-Talib, A.N. (2015b), "Boycott and racism: a loaf of bread is just a loaf of bread”, Emerald Emerging Markets Case Studies, Vol. 5 No. 6, pp. 1-13, doi: 10.1108/eemcs-092014-0224.

Abdul-Latif, S.A. and Abdul-Talib, A.N. (2017), "Consumer racism: a scale modification", Asia Pacific Journal of Marketing and Logistics, Vol. 29 No. 3, pp. 616-633, doi: 10.1108/APJML02-2016-0026.

Abdul-Talib, A.N. and Abdul-Latif, S.A. (2015), "Antecedents to willingness to boycott amongst Malaysian Muslims", in El-Gohary, H. and Eid, R. (Eds), Emerging Research on Islamic Marketing and Tourism in the Global Economy, IGI Global, Hershey PA, pp. 70-106, doi: 10.4018/ 978-1-4666-6272-8.

Abdul-Talib, A.N. and Mohd Muttaqin, M.A. (2017), "Determinants of consumer's willingness to boycott surrogate products", Journal of Islamic Marketing, Vol. 4 No. 1, pp. 2013-2014, doi: 10.1108/17590831311306336.

Ahmed, S.A. and d'Astous, A. (2007), "Moderating effect of nationality on country-of-origin perceptions: English-speaking Thailand versus French-speaking Canada", Journal of Business Research, Vol. 60 No. 3, pp. 240-248, doi: 10.1016/j.jbusres.2006.11.004.

Ahmed, Z.U., Hinck, W. and Felix, R. (2018), "Twenty-five years after the fall of the Berlin wall: an empirical revisit of West German consumers' attitudes toward products and brands from former East Germany”, Journal of Promotion Management, Vol. 24 No. 6, pp. 895-910.

Ahmed, Z., Anang, R., Othman, N. and Sambasivan, M. (2013), "To purchase or not to purchase US products: role of religiosity, animosity, and ethnocentrism amongst Malaysian consumers", Journal of Services Marketing, Vol. 27 No. 7, pp. 551-563, doi: 10.1108/JSM01-2012-0023.

Alam, S.S. and Sayuti, N.M. (2011), "Applying the theory of planned behavior (TPB) in halal food purchasing", International Journal of Commerce and Management, Vol. 21 No. 1, pp. 8-20, doi: $10.1108 / 10569211111111676$.

Alatas, S.H. (1977), The Myth of the Lazy Native, Frank Cass and Company Ltd, OR, doi: 10.2307/ 1866085.

Ali, S.H. (2008), The Malays, Their Problems and Future, The Other Press, Kuala Lumpur. 
Amine, L.S. (2008), "Country-of-origin, animosity and consumer response: marketing implications of anti-Americanism and francophobia", International Business Review, Vol. 17 No. 4, pp. 402-422, doi: 10.1016/j.ibusrev.2008.02.013.

Anderson, J. and Gerbing, D. (1988), "Structural equation modeling in practice: a review and recommended two-step approach”, Psychological Bulletin, Vol. 103 No. 3, pp. 411-423, doi: 10.1037/0033-2909.103.3.411.

Ang, S.H., Jung, K., Kau, A.K., Leong, S.M., Pornpitakpan, C. and Tan, S.J. (2004), “Animosity towards economic giants: what the little guys think", Journal of Consumer Marketing, Vol. 21 No. 3, pp. 190-207, doi: 10.1108/07363760410534740.

Antonetti, P., Manika, D. and Katsikeas, C. (2019), "Why consumer animosity reduces product quality perceptions: the role of extreme emotions in international crises", International Business Review, Vol. 28 No. 4, pp. 739-753.

Asri, M. and Ghani, A. (2012), "Transformasi dan prestasi perniagaan usahawan melayu perusahaan kecil dan sederhana (PKS) di Johor bahru transformation and business performance of malay entrepreneurs in small and medium enterprises in Johor", in Prosiding PERKEM VII: Transformasi Ekonomi Dan Sosial ke Arah Negara Maju, Vol. 1, pp. 696-708.

Antonio, F. and Astika, P. (2019), "The antecedents of consumption value and its impact on customer behavior; a study of batik cloth on non-javanese Indonesian millennials", International Journal of Applied Business and International Management, Vol. 4 No. 1, pp. 46-58.

Awang, Z., Wan Afthanorhan, W.M.A. and Asri, M. A M. (2015), "Parametric and non parametric approach in structural equation modeling (SEM): the application of bootstrapping", Modern Applied Science, Vol. 9 No. 9, pp. 58-67, doi: 10.5539/mas.v9n9p58.

Awaluddin, I. and Hamid, W. (2019), "Interaction of social identity, empathy and planned behavior theories to understand domestic product purchasing intention", Problems and Perspectives in Management, Vol. 17 No. 1, pp. 95-102.

Azhar, K. and Aliman, K.H. (2018), "Cover story: a case of too many bumiputera development agencies", Edge Weekly, pp. 1-11, available at: www.theedgemarkets.com/article/cover-storycase-too-many-bumiputera-development-agencies

Bahaee, M. and Pisani, M. (2009a), "Iranian consumer animosity and US products: a witch's brew or elixir?", International Business Review, Vol. 18 No. 2, pp. 199-210, doi: 10.1016/j. ibusrev.2009.02.002.

Bahaee, M. and Pisani, M. (2009b), "The use of the consumer ethnocentrism and consumer animosity scales in Iran: a research note", Thunderbird International Business Review, Vol. 51 No. 2, pp. 143-151, doi: 10.1002/tie.

Bahaee, M. and Pisani, M.J. (2009c), "Are Iranian consumers poised to 'buy American' in a hostile bilateral environment?, Business Horizons, Vol. 52 No. 3, pp. 223-232, doi: 10.1016/j. bushor.2008.11.004.

Baharuddin, S.A. (2012), Modul Hubungan Etnik, Institut Kajian Etnik, Universiti Kebangsaan Malaysia.

Balabanis, G. and Diamantopoulos, A. (2011), "Gains and losses from the misperception of brand origin: the role of brand strength and country-of-origin image", Journal of International Marketing, Vol. 19 No. 2, pp. 95-116, doi: 10.1509/jimk.19.2.95.

Balabanis, G., Diamantopoulos, A., Mueller, R.D. and Melewar, T. (2001), "The impact of nationalism, patriotism and internationalism on consumer ethnocentric tendencies", Journal of International Business Studies, Vol. 32 No. 1, pp. 157-175.

Bentler, P.M. (1990), "Comparative fit indexes in structural models", Psychological Bulletin, Vol. 107 No. 2, p. 238. 
Bentler, P.M. and Bonett, D.G. (1980), "Significance tests and goodness of fit in the analysis of covariance structures", Psychological Bulletin, Vol. 88 No. 3, p. 588.

Brown, S. (1987), "Drop and collect surveys: a neglected research technique?", Marketing Intelligence and Planning, Vol. 5 No. 1, pp. 19-23.

Browne, M.W. and Cudeck, R. (1993), "Alternative ways of assessing model fit", in Bollen, K.A. and Long, J.S. (Eds), Testing Structural Equation Models, Sage Publications, Thousand Oaks, CA, pp. 136-162.

Bustaman, H.A. and Yunus, O.M. (2012), "Success in business: do the Malays hold the right values?", Proceedings of the ASEAN Entrepreneurship Conference 2012, pp. 3-8.

Carter, L.L. and Maher, A.A. (2014), “Assessing consumers' willingness to buy foreign goods: an integrative modeling approach”, International Journal of Marketing Studies, Vol. 6 No. 3, pp. 23-34, doi: 10.5539/ijms.v6n3p23.

Chowdhury, T.G., Elahee, M. and Branchik, B. (2019), "Examining ethnocentrism in an age of hybrid consumers and hybrid brands: an empirical analysis examining ethnocentrism in an age of hybrid consumers and hybrid", Journal of International Consumer Marketing, Vol. 31 No. 4, pp. 1-15, doi: 10.1080/08961530.2018.1564107.

Chryssochoidis, G., Krystallis, A. and Perreas, P. (2007), "Ethnocentric beliefs and country-of-origin (COO) effect: impact of country, product and product attributes on Greek consumers' evaluation of food products", European Journal of Marketing, Vol. 41 Nos 11/12, pp. 1518-1544, doi: 10.1108/ 03090560710821288.

Darling, J.R. and Puetz, J.E. (2002), "Analysis of changes in consumer attitudes toward the products of England, France, Germany and the USA, 1975-2000", European Business Review, Vol. 14 No. 14, pp. 170-183.

Department of Statistics, Malaysia (2018), available at :www.dosm.gov.my/v1/index.php?r=column/ pdfPrev\&id=c1pqTnFjb29HSnNYNUpiTmNWZHArdz09 (accessed 23 December 2019).

Devellis, R.F. (2003), Scale Development Theory and Applications, 2nd ed., Vol. 26, SAGE Publications, London.

Dursun, I., Kabadayi, E.T., Ceylan, K.E. and Koksal, C.G. (2019), "Russian consumers' responses to Turkish products: exploring the roles of country image, consumer ethnocentrism, and animosity", Business and Economics Research Journal, Vol. 10 No. 2, pp. 499-516.

Erba, J., Zhang, D. and Liu, Y. (2019), "Exploring the role of ethnic and bi-ethnic identities in advertisements targeting Chinese and Chinese-American consumers using celebrity athletes", China Media Research, Vol. 15 No. 1, pp. 67-76.

Ettenson, R. (1993), "Brand name and country of origin effects in the emerging market economies of Russia, Poland and Hungary", International Marketing Review, Vol. 10 No. 5.

Ettenson, R. and Klein, J.G. (2005), "The fallout from French nuclear testing in the South Pacific: a longitudinal study of consumer boycotts", International Marketing Review, Vol. 22 No. 2, pp. 199-224, doi: 10.1108/02651330510593278.

Fernández-Ferrín, P. and Bande-Vilela, B. (2013), "Regional ethnocentrism: antecedents, consequences, and moderating effects", Food Quality and Preference, Vol. 30 No. 2, pp. 299-308.

Fernández-Ferrín, P., Bande-Vilela, B., Klein, J.G. and Río-Araújo, M.L. (2015), "Consumer ethnocentrism and consumer animosity: antecedents and consequences", International Journal of Emerging Markets, Vol. 10 No. 1, pp. 73-88, doi: 10.1108/IJOEM-08-2012-00102.

Ferrín, P.F. and Vilela, B.B. (2015), "Attitudes and reactions of Galician (Spanish) consumers towards the purchase of products from other regions", Global Business and Economics Review, Vol. 17 No. 2, p. 131, doi: 10.1504/GBER.2015.068563.

FMT (2019), “Dr M, DAP promoted 'buy Muslim-made first' campaign, says Najib”, Retrieved February 22, 2020, available at :www.freemalaysiatoday.com/category/nation/2019/09/11/dr-mdap-promoted-buy-muslim-made-first-campaign-says-najib/ 
Ganideh, S.F.A. and Elahee, M. (2016), "Dealing with 'enemy-brothers': Sunni-Arab consumers' animosity toward Iran and Turkey”, Journal of Consumer Marketing, doi: 10.1108/JCM-08-20161919.

Gao, Z., Xu, J. and Kim, J.H. (2013), “The effect of racial cues on the reader's response to advertisements: a US-China comparative study", Asia Pacific Journal of Marketing and Logistics, Vol. 25 No. 3, pp. 510-532, doi: 10.1108/APJML-11-2012-0120.

Gaskin, J. (2016), "SEM series (2016) 5. Confirmatory factor analysis part 2”, available at: www.youtube. $\mathrm{com} /$ watch? $\mathrm{v}=$ CFBUECZgUuo

Gaur, J., Amini, M., Banerjee, P. and Gupta, R. (2015), "Drivers of consumer purchase intentions for remanufactured products: a study of Indian consumers relocated to the USA", Qualitative Market Research: An International Journal, Vol. 18 No. 1, pp. 30-47.

Gomez, E.T. (2003), "Affirmative action and enterprise development in Malaysia: the new economic policy, business partnerships and inter-ethnic relations", Kajian Malaysia, Vol. 21 No. 1/2, pp. 59-104.

Grier, S.A., Brumbaugh, A.M. and Thornton, C.G. (2006), "Crossover dreams: consumer responses to ethnic-oriented products", Journal of Marketing, Vol. 70 No. 2, pp. 35-51, doi: 10.1509/ jmkg.70.2.35.

Gupta, O.J. and Singh, A. (2019), "Consumer animosity towards Chinese products: a case of India", Consumer Animosity Towards Chinese Products: A Case of India, Vol. 8 No. 1, pp. 43-57, available at: https://search.proquest.com/docview/2215508655?accountid=14744\%0Ahttps:// cbua-us.primo.exlibrisgroup.com/discovery/openurl?institution=34CBUA_US\&vid=34CBUA_US: VU1\&lang=es?url_ver=Z39.88-2004\&rft_val_fmt=info:ofi/fmt:kev:mtx:journal\&genre=article\& sid=ProQ:

Hair, J.F.J., Black, W.C., Babin, B.J., Anderson, R.E. and Tatham, R.L. (2009), Multivariate Data Analysis, 6th ed., Pearson Education, NJ.

HaminElliott, G. (2006), "A less-developed country perspective of consumer ethnocentrism and 'country of origin' effects: Indonesian evidence", Asia Pacific Journal of Marketing and Logistics, Vol. 18 No. 2, pp. 79-92, doi: 10.1108/13555850610658246.

Hamzah, H. and Mustafa, H. (2019), "Exploring consumer boycott intelligence towards Israel-related companies in Malaysia: an integration of the theory of planned behaviour with transtheoretical stages of change", Journal of Islamic Marketing, Vol. 10 No. 1, pp. 208-226.

Hegner, S.M., Fetscherin, M. and van Delzen, M. (2017), "Determinants and outcomes of brand hate", Journal of Product and Brand Management, Vol. 26 No. 1, pp. 13-25.

Hill, S.R. and Paphitis, K. (2011), "Can consumers be racist? An investigation of the effect of consumer racism on product purchase", Asia Pacific Journal of Marketing and Logistics, Vol. 23 No. 1, pp. 57-71, doi: $10.1108 / 13555851111099998$.

Hinck, W. (2005), "The role of domestic animosity in consumer choice: empirical evidence from Germany”, Journal of Euromarketing, Vol. 14 Nos 1/2, pp. 87-104, doi: 10.1300/J037v14n01_05.

Hoffmann, S., Mai, R. and Smirnova, M. (2011), "Development and validation of a cross-nationally stable scale of consumer animosity", Journal of Marketing Theory and Practice, Vol. 19 No. 2, pp. 235-252, doi: 10.2753/MTP1069-6679190208.

Hong, S.T. and Kang, D.K. (2006), "Country-of-origin influences on product evaluations: the impact of animosity and perceptions of industriousness brutality on judgments of typical and atypical products", Journal of Consumer Psychology, Vol. 16 No. 3, pp. 232-239.

Huang, Y.A., Lin, C. and Yen, D.A. (2015), "Animosity within borders: the mediating roles of regional identification and perceived discrimination on regional media preference", Asia Pacific Journal of Marketing and Logistics, Vol. 27 No. 5, pp. 692-716.

Idris, A. (2008), "An analysis of Malay-Sino relations in Malaysia”, Asian Social Science, Vol. 4 No. 2, pp. 3-12. 
Jamaluddin, A. and Dickie, C. (2011), "Decision-making related to business growth: Malay small businesses in Selangor", International Journal of Business and Management, Vol. 6 No. 10, pp. 284-296, doi: 10.5539/ijbm.v6n10p284.

Jung, K., Ang, S.H., Leong, S.M., Tan, S.J., Pornpitakpan, C. and Kau, A.K. (2002), “A typology of animosity and its cross-national validation”, Journal of Cross-Cultural Psychology, Vol. 33 No. 6, pp. 525-539, doi: 10.1177/0022022102238267.

Kipnis, E., Demangeot, C., Pullig, C. and Broderick, A.J. (2019), "Consumer multicultural identity affiliation: reassessing identity segmentation in multicultural markets", Journal of Business Research, Vol. 98, pp. 126-141.

Khairil Anwar, M.A. (2019), "Kempen BMF tingkat jualan peniaga islam tiga kali ganda", Retrieved October 25, 2020, available at: www.sinarharian.com.my/article/47663/BERITA/Nasional/ Kempen-BMF-tingkat-jualan-peniaga-Islam-tiga-kali-ganda

Khan, H., Daryanto, A. and Liu, C. (2019), "How anticipated regret influences the effect of economic animosity on consumers' reactions towards a foreign product", International Business Review, Vol. 28 No. 2, pp. 405-414.

Khan, H., Lee, R., Lockshin, L. and Lockshin, L. (2017), "The effects of packaging localisation of Western brands in non-Western emerging markets", Journal of Product and Brand Management, Vol. 26 No. 6, pp. 589-599, doi: 10.1108/JPBM-08-2016-1302.

Karoui, S. and Khemakhem, R. (2019), "Consumer ethnocentrism in developing countries", European Research on Management and Business Economics, Vol. 25 No. 2, pp. 63-71.

Klein, J.G. (2002), "Us versus them, or Us versus everyone? Delineating consumer aversion to foreign goods", Journal of International Business Studies, Vol. 33 No. 2, pp. 345-363.

Klein, J.G. and Ettenson, R. (1999), "Consumer animosity and consumer ethnocentrism: an analysis of unique antecedents", Journal of International Consumer Marketing, Vol. 11 No. 4, pp. 5-24.

Klein, J.G., Ettenson, R. and Krishnan, B.C. (2006), "Extending the construct of consumer ethnocentrism: when foreign products are preferred", International Marketing Review, Vol. 23 No. 3, pp. 304-321, doi: 10.1108/02651330610670460.

Klein, J.G., Ettenson, R. and Morris, M.D. (1998), "The animosity model of foreign product purchase: an empirical test in the People's Republic of China”, Journal of Marketing, Vol. 62 No. 1, p. 89, doi: 10.2307/1251805.

Kline, R.B. (2011), Principles and Practice of Structural Equation Modeling, 3rd ed., The Guilford Press, New York, NY.

Kua, K.S. (2011), May 13: Declassified Documents on the Malaysian Riots of 1969, Suaram.

Lee, Y.F. (2014), Identiti Cina Malaysia, Penerbit Universiti Malaya, Kuala Lumpur.

Lee, R. and Mazodier, M. (2015), "The roles of consumer ethnocentrism, animosity, and cosmopolitanism in sponsorship effects", European Journal of Marketing, Vol. 49 Nos 5/6, doi: 10.1108/EUM0000000001104.

Leonidou, L.C., Kvasova, O., Christodoulides, P. and Tokar, S. (2019), "Personality traits, consumer animosity, and foreign product avoidance: the moderating role of individual cultural characteristics", Journal of International Marketing, Vol. 27 No. 2, pp. 76-96.

Li, C., Tsai, S. and Soruco, G. (2013), "Perceived 'Hispanicness' versus 'Americanness': a study of brand ethnicity with Hispanic consumers", International Journal of Advertising, Vol. 32 No. 3, pp. 443-465, doi: 10.2501/IJA-32-3-443-465.

Liu, A. (2006), "Tourism in rural areas: Kedah, Malaysia", Tourism Management, Vol. 27 No. 5, pp. 878-889, doi: 10.1016/j.tourman.2005.05.007.

Lowry, P.B. and Gaskin, J. (2014), "Partial least squares (PLS) structural equation modeling (SEM) for building and testing behavioral causal theory: when to choose it and how to use it", Ieee Transactions on Professional Communication, Vol. 57 No. 2, pp. 123-146. 
Luque-Martinez, T., Ibanez-Zapata, J. and Barrio-Garcia, S.D. (2000), “An assessment of the reliability and validity of the CETSCALE in Spain consumer ethnocentrism measurement", European Journal of Marketing, Vol. 34 No. 11, pp. 1353-1373.

Maher, A.A. and Mady, S. (2010), "Animosity, subjective norms, and anticipated emotions during an international crisis", International Marketing Review, Vol. 27 No. 6, pp. 630-651, doi: 10.1108/ 02651331011088263.

Maher, A.A., Clark, P. and Maher, A. (2010), "International consumer admiration and the persistence of animosity", Journal of Consumer Marketing, Vol. 27 No. 5, pp. 414-424, doi: 10.1108/ 07363761011063312.

Minai, M.S., Ibrahim, Y. and Kheng, L.K. (2012), "Entrepreneurial network in Malaysia: are there any differences across ethnic groups?", Journal of Business and Policy Research, Vol. 7 No. 1, pp. 178-192.

Mostafa, M.M. (2010), "A structural equation analysis of the animosity model of foreign product purchase in Egypt”, Global Business Review, Vol. 11 No. 3, pp. 347-363, doi: 10.1177/ 097215091001100303.

Muhamad, N., Khamarudin, M. and Fauzi, W.I.M. (2019), "The role of religious motivation in an international consumer boycott”, British Food Journal, Vol. 121 No. 1, pp. 199-217, available at: https://doi.org/10.1108/BFJ-02-2018-0118

Muhammad, N. and Che Razak, R. (2004), "Consumer ethnocentrism: the relationship with domestic products evaluation and buying preferences", International Journal of Management Studies, Vol. 11, pp. 29-44, available at: http://onlinelibrary.wiley.com/doi/10.1002/cbdv.200490137/ abstract

Muzaffar, C. (2010), A Plea for Empathy: The Quest for Malaysian Unity, Zubedy Ideahouse, Kuala Lumpur.

Netemeyer, R.G., Bearden, W.O. and Sharma, S. (2003), Scaling Procedures: Issues and Applications, Sage Publications, Thousand Oaks, CA, doi: 10.1017/CBO9781107415324.004.

Nijssen, E.J. and Douglas, S.P. (2004), "Examining the animosity model in a country with a high level of foreign trade", International Journal of Research in Marketing, Vol. 21 No. 1, pp. 23-38.

O'Hagan-Luff, M. and Berrill, J. (2016), "US firms - how global are they? A longitudinal study", International Review of Financial Analysis, Vol. 44, pp. 205-216, doi: 10.1016/j.irfa.2016.01.021.

Olmedo, E., Smith, W. and Mohd Noor, M. (2015), "Ethnic groupism: understanding ethnicisation of work in Malaysia”, Ethnicities, Vol. 15 No. 6, pp. 1-19, doi: 10.1177/1468796815581427.

Ouellet, J.F. (2007), "Consumer racism and its effects on domestic cross-ethnic product purchase: an empirical test in the", Journal of Marketing, Vol. 71 No. 1, pp. 113-128.

Pentz, C., Terblanche, N. and Boshoff, C. (2017), "Antecedents and consequences of consumer ethnocentrism: evidence from South Africa”, International Journal of Emerging Markets, Vol. 12 No. 2, pp. 199-218, doi: 10.1108/IJoEM-09-2015-0189.

Pires, G. and Stanton, J. (2000), "Marketing services to ethnic consumers in culturally diverse markets: issues and implications”, Journal of Services Marketing, Vol. 14 No. 7, pp. 607-618, doi: 10.1108/ 08876040010352772.

Podsakoff, P.M., MacKenzie, S.B., Lee, J.Y. and Podsakoff, N.P. (2003), "Common method biases in behavioral research: a critical review of the literature and recommended remedies", Journal of Applied Psychology, Vol. 88 No. 5, pp. 879-903, doi: 10.1037/0021-9010.88.5.879.

Poon, P., Evangelista, F. and Albaum, G. (2010), "Attitudes of migrants towards foreign-made products: an exploratory study of migrants in Australia”, Journal of Consumer Marketing, Vol. 27 No. 1, pp. 35-42, doi: 10.1108/07363761011012930.

Putra, T.A.R. (2012), 13 Mei Sebelum Dan Selepas, 3rd ed., Utusan Publication and Distributors, Kuala Lumpur. 
Qing, P., Lobo, A. and Chongguang, L. (2012), “The impact of lifestyle and ethnocentrism on consumers' purchase intentions of fresh fruit in China", Journal of Consumer Marketing, Vol. 29 No. 1, pp. 43-51, doi: 10.1108/07363761211193037.

Riefler, P. and Diamantopoulos, A. (2007), "Consumer animosity: a literature review and a reconsideration of its measurement”, International Marketing Review, Vol. 24 No. 1, pp. 87-119, doi: $10.1108 / 02651330710727204$.

Rose, M., Rose, G.M. and Shoham, A. (2009), "The impact of consumer animosity on attitudes towards foreign goods: a study of Jewish and Arab Israelis", Journal of Consumer Marketing, Vol. 26 No. 5, pp. 330-339, doi: 10.1108/07363760910976583.

Sabiu, I.T., Abdullah, A., Amin, A. and Tahir, I.M. (2018), "An empirical analysis of the need for achievement motivation in predicting entrepreneurial persistence in Bumiputra entrepreneurs in Terengganu", International Journal of Business and Globalisation, Vol. 20 No. 2, p. 190, doi: 10.1504/IJBG.2018.089867.

Saffu, K., Walker, J.H. and Mazurek, M. (2010), "The role of consumer ethnocentrism in a buy national campaign in a transitioning country: some evidence from Slovakia”, International Journal of Emerging Markets, Vol. 5 No. 2, pp. 203-226.

Seidenfuss, K.U., Kathawala, Y. and Dinnie, K. (2013), "Regional and country ethnocentrism: broadening ASEAN origin perspectives", Asia Pacific Journal of Marketing and Logistics, Vol. 25 No. 2, pp. 298-320, doi: 10.1108/13555851311314077.

Shankarmahesh, M.N. (2006), "Consumer ethnocentrism: an integrative review of its antecedents and consequences", International Marketing Review, Vol. 23 No. 2, pp. 146-172, doi: 10.1108/ 02651330610660065.

Sharma, P. (2014), "Consumer ethnocentrism: reconceptualization and cross-cultural validation", Journal of International Business Studies, Vol. 46 No. 3, pp. 1-9, doi: 10.1057/jibs.2014.42.

Sharma, S., Shimp, T.A. and Shin, J. (1995), "Consumer ethnocentrism: a test of antecedents and moderators", Journal of the Academy of Marketing Science, Vol. 23 No. 1, pp. 26-37.

Shimp, T.A. and Sharma, S. (1987), "Consumer ethnocentrism: Construction and validation of the CETSCALE”, Journal of Marketing Research, Vol. 24 No. 3, pp. 280-289.

Shimp, T.A., Dunn, T.H. and Klein, J.G. (2004), "Remnants of the U.S. Civil war and modern consumer behavior", Psychology and Marketing, Vol. 21 No. 2, pp. 75-91, doi: 10.1002/mar.10116.

Shoham, A., Davidow, M., Klein, J.G. and Ruvio, A. (2006), "Animosity on the home front: the intifada in Israel and its impact on consumer behavior", Journal of International Marketing, Vol. 14 No. 3, pp. 92-114, doi: 10.1509/jimk.14.3.92.

Siamagka, N.T. and Balabanis, G. (2015), "Revisiting consumer ethnocentrism: review, reconceptualization, and empirical testing", Journal of International Marketing, Vol. 23 No. 3, pp. 66-86, doi: 10.1509/jim.15.0085.

Siemieniako, D., Kubacki, K., Gli\#Ska, E., Krot, K., Glinska, E. and Krot, K. (2011), "National and regional ethnocentrism: a case study of beer consumers in Poland", British Food Journal, Vol. 113 No. 3, pp. 404-418.

Sierra, J. and McQuitty, S. (2007), "Attitudes and emotions as determinants of nostalgia purchases: an application of social identity theory", Journal of Marketing Theory and Practice, Vol. 15 No. 2, pp. 99-112, doi: 10.2753/MTP1069-6679150201.

Stoltman, J.J., Lim, Y.K. and Morgan, F.W. (1991), "The effect of country of origin, product familiarity and ethnocentrism on the acceptance of foreign products", Marketing Theory and Applications, Academy of Marketing Winter Educators Conference, International Business Press, pp. 82-89.

Suryanidata, L. (2007), "Ethnic Chinese in Southeast Asia: problems and prospects", Understanding the Ethnic Chinese in Southeast Asia, Institute of Southeast Asian Studies, Singapore, pp. 11-28. 
Tajfel, H. (1974), "Social identity and intergroup behaviour", Social Science Information, Vol. 13 No. 2, pp. 65-93, doi: 10.1177/053901847401300204.

Tajfel, H. and Turner, J. (1986), “The social identity theory of intergroup behavior”, in Austin, W.G. and Worchel, S. (Eds), Psychology of Intergroup Relations, Nelson-Hall Chicago, Chicago, pp. 7-24.

Teo, P., Mohamad, O. and Ramayah, T. (2011), "Testing the dimensionality of consumer ethnocentrism scale (CETSCALE) amongst a young Malaysian consumer market segment”, A frican Journal of Business Management, Vol. 5 No. 7, pp. 2805-2816, doi: 10.5897/AJBM10.1185.

Vengadesan, M. (2008), "May 13, 1969: truth and reconciliation", available at: www.thestar.com.my/ story $/$ file $=\% 2 \mathrm{~F} 2008 \% 2 \mathrm{~F} 5 \% 2 \mathrm{~F} 11 \% 2 \mathrm{Flifefocus} \% 2 \mathrm{~F} 21181089$

Verlegh, P.W.J. (2007), "Home country bias in product evaluation: the complementary roles of economic and socio-psychological motives", Journal of International Business Studies, Vol. 38 No. 3, pp. 361-373, doi: 10.1057/palgrave.jibs.8400269.

Vida, I., Dmitrovic, T. and Obadia, C. (2008), "The role of ethnic affiliation in consumer ethnocentrism”, European Journal of Marketing, Vol. 42 Nos 3/4, pp. 327-343, doi: 10.1108/ 03090560810852968.

Wan Husin, W.N. (2012), Peradaban Dan Perkauman di Malaysia: Hubungan Etnik Melayu-Cina, Penerbit Universiti Malaya, Kuala Lumpur.

Wan Husin, W.N. (2013), "Business dominance amongst the Malays and Chinese in Malaysia from a civilizational perspectives", International Journal of Social Science and Humanity, Vol. 3 No. 4, pp. 360-364, doi: 10.7763/IJSSH.2013.V3.262.

Wan Husin, W.N. and Ong, J.H. (2012), "The role of culture in strengthening Chinese business survival during Malaysian new economic policy", International Proceedings of Economics Development and Research, Vol. 48 No. 16, pp. 73-77, doi: 10.7763/IPEDR.

Wang, C.L. and Chen, Z.X. (2004), "Consumer ethnocentrism and willingness to buy domestic products in a developing country setting: testing moderating effects", Journal of Consumer Marketing, Vol. 21 No. 6, pp. 391-400, doi: 10.1108/07363760410558663.

Wang, W., He, H., Sahadev, S. and Song, W. (2018), "UK consumers' perceived risk of buying products from emerging economies: a moderated mediation model", Journal of Consumer Behaviour, Vol. 17 No. 3, pp. 326-339.

Watson, J.J. and Wright, K. (2000), "Consumer ethnocentrism and attitudes toward domestic and foreign products”, European Journal of Marketing, Vol. 34 Nos 9/10, pp. 1149-1166, doi: 10.1108/ 03090560010342520.

Wheaton, B., Muthen, B., Alwin, D.F. and Summers, G.F. (1977), "Assessing reliability and stability in panel models", Sociological Methodology, Vol. 8 No. 1, pp. 84-136.

Wilson, J.A.J. and Grant, J. (2013), "Islamic marketing - a challenger to the classical marketing canon?", Journal of Islamic Marketing, Vol. 4 No. 1, pp. 7-21, doi: 10.1108/ 17590831311306327.

Wilson, J.A.J. and Liu, J. (2011), "The challenges of Islamic branding: navigating emotions and halal", Journal of Islamic Marketing, Vol. 2 No. 1, pp. 28-42, doi: 10.1108/17590831111115222.

Wilson, J.A.J., Belk, R.W., Bamossy, G.J., Sandikci, Ö., Kartajaya, H., Sobh, R., .. Scott, L. (2013), "Crescent marketing, Muslim geographies and brand Islam: reflections from the JIMA senior advisory board", Journal of Islamic Marketing, Vol. 4 No. 1, pp. 22-50, doi: 10.1108/ 17590831311306336.

Witkowski, T. (2000), "Effects of animosity toward China on willingness to buy Chinese products", Managing in a Turbulent International Business Environment, pp. 470-477.

Yagci, M.I. (2001), "Evaluating the effects of country-of-origin and consumer ethnocentrism: a case of a transplant product", Journal of International Consumer Marketing, Vol. 13 No. 3, pp. 63-85. 
Zakaria, N., Wan-Ismail, W.N.A. and Abdul-Talib, A.N. (2020), "Seriously, conspicuous consumption? The impact of culture, materialism and religiosity on Malaysian generation Y consumers' purchasing of foreign brands", Asia Pacific Journal of Marketing and Logistics, doi: 10.1108/ APJML-07-2018-0283.

Zarantonello, L., Romani, S., Grappi, S., Bagozzi, R.P., Zarantonello, L., Romani, S. and Grappi, S. (2016), "Brand hate", Journal of Product and Brand Management, Vol. 25 No. 1, pp. 11-25, doi: 10.1108/ JPBM-01-2015-0799.

Zeugner-Roth, K.P., Žabkar, V. and Diamantopoulos, A. (2015), "Consumer ethnocentrism, national identity, and consumer cosmopolitanism as drivers of consumer behavior: a social identity theory perspective”, Journal of International Marketing, Vol. 23 No. 2, pp. 25-54, doi: 10.1509/ jim.14.0038.

\section{Further readings}

Abdul-Talib, A.N., Abd-Latif, S.A. and Abd-Razak, I.S. (2016), "A study on the boycott motivations of Malaysian non-Muslims”, Journal of Islamic Marketing, Vol. 7 No. 3, pp. 264-287, doi: 10.1108/ JIMA-11-2014-0071.

Census (2011), "Population distribution and basic demographic characteristics 2010", Dept of Statistics, Malaysia, pp. 1-133. 
Items Constructs

$E B C E$

CET1 Malays should always buy Malay-made products

CET2 A good Malay does not buy local/domestic products made by any other ethnic group except for Malay

CET4 We should purchase domestic/local products manufactured by Malays instead of letting other ethnic groups in this country get rich off us

CET5 We should only buy local/domestic products from other ethnic groups, if we cannot obtain the products from our own people. Buy Malay-made products

CET6 Keep Malays working, in business and rich

CET7 Malay products, first, last and foremost

CET8 A real Malay should always buy Malay-made products

CET9 It is always best to purchase Malay products

CET10 It may cost me more but I prefer to support Malay products

\section{Ethic-based consumer animosity}

CA4 Malaysian Chinese should pay for marginalizing and discriminating against Malays

CA5 Malaysian Chinese are not reliable trading partners

CA6 Malaysian Chinese are taking advantage of the Malay majority

CA7 Malaysian Chinese have too much economic influence in Malaysia

CA8 Malaysian Chinese are doing business unfairly with the Malay majority

\section{Product judgment}

PJ1 Malaysian Chinese products are carefully produced and have fine workmanship

PJ2 Malaysian Chinese products show a very high degree of technological advancement

PJ3 Malaysian Chinese products show a very clever use of color and design

PJ4 Malaysian Chinese products usually are quite reliable and seem to last the desired length of time

Willingness to buy

WTB1 I would feel guilty if I bought Malaysian Chinese products

WTB2 I would never buy Malaysian Chinese products

Table A1.

Item loadings

WTB3 Whenever possible, I avoid Malaysian Chinese products

WTB4 I do not like the idea of owning Malaysian Chinese products

\section{Corresponding author}

Asmat-Nizam Abdul-Talib can be contacted at: asmat@uum.edu.my

For instructions on how to order reprints of this article, please visit our website: 